\title{
Analisis Pengelolaan Dana Desa Pranten Kecamatan Gubug Kabupaten Grobogan
}

\author{
Ferry Khusnul Mubarok, Farikhatul Liana Annisak \\ Fakultas Ekonomi dan Bisnis Islam Universitas Islam Negeri Walisongo Semarang \\ Jln. Prof. Dr. Hamka Kampus III UIN Walisongo Semarang, Indonesia
}

Kata Kunci:

Pengelolaan, Pemanfaatan, Kendala, Alokasi Dana Desa, BUMDes.

Keywords:

Management, Utilization, Constraints, Village Fund Allocation, BUMDes.

Corresponding author: ferrykhusnul mubarok@walisongo.ac.id

\section{ABSTRAK}

Studi ini bertujuan untuk menganalisis pengelolaan Dana Desa, pada Desa Pranten Kecamatan Gubug Kabupaten Grobogan. Metode penelitian menggunakan pendekatan kualitatif eksploratif, dengan sumber data primer dengan teknik indept interview. Teknik analisis data menggunakan pendekatan descriptive analysis. Hasil penelitian menunjukkan bahwa pengelolaan dan pemanfaatan Anggaran Dana Desa dimulai dari proses perencanaan, pengorganisasian, pelaksanaan, pengawasan, dan pelaporan pertanggungjawaban. Pemanfaatan dana desa dialokasikan pada bidang penyelenggaran pemerintah, pelaksanaan pembangunan, pembinaan masyarakat, pemberdayaan masyarakat, dan penanggulangan bencana. Kendala yang muncul antara lain rendahnya kualitas sumber daya manusia, minimnya sistem, masalah kepemimpinan, kurangnya sosialisasi dan komunikasi, serta peran masyarakat yang rendah. Implikasinya, kedepan pemerintah desa setempat perlu meningkatkan kualitas pengelolaan anggaran dan membangun sinergi dengan berbagai pihak terkait terutama dengan warga masyarakat.

\section{ABSTRACT}

This study aims to analyze the management of the Village Fund in Pranten Village, Gubug District, Grobogan Regency. The research method uses an exploratory qualitative approach, using in-depth interview techniques and primary data sources. The data analysis technique used a descriptive analysis approach. The study results indicate that the management and utilization of the Village Fund Budget start from the planning, organizing, implementation, monitoring, and accountability reporting processes. Village funds are utilized in government administration, implementation of development, community development, community empowerment, and disaster management. Constraints that arise include the low quality of human resources, lack of systems, leadership problems, lack of socialization and communication, and low community roles. The implication is that in the future, the local village government needs to improve the quality of budget management and build synergies with various related parties, especially with community members. 
Studi Akuntansi \& Keuangan Indonesia

\section{Pendahuluan}

Tujuan pembangunan ekonomi adalah untuk mencapai pemerataan pembangunan di semua wilayah. Pembangunan berdasarkan sistem sentralistik memiliki kelemahan, sehingga pemerintah berinisiatif memberikan kewenangan masing-masing daerah untuk mengelola anggarannya secara mandiri atau dikenal dengan otonomi daerah (Yoga et al., 2019). Otonomi daerah mempunyai dampak signifikan terhadap pemerataan (Saputra, 2016). Desentralisasi kewenangan pemerintah pusat ke daerah memberikan peluang kepada daerah untuk membangun perekonomian (Tikollah dan Ngampo, 2018). Otonomi daerah memberi kesempatan kepada daerah untuk mengoptimalkan pengelolaan dan pemanfaatan sumberdaya daerahnya. Otonomi daerah menjadi tantangan tersendiri untuk mendorong kreativitas dalam menghadapi berbagai permasalahan domestik, terutama dalam rangka mengejar kesejahteraan (Inten, 2017). Walaupun titik tumpu otonomi daerah berada di kabupaten/kota, tetapi secara esensi kemandirian tersebut harus dimulai dari tingkat paling bawah yaitu Desa (Wida et al., 2017). Sampai detik ini, kewenangan pengelolaan anggaran sudah sampai pada tingkat Desa, bahkan di setiap Desa diberikan dana dari pemerintah pusat untuk membangun desanya yang disebut Alokasi Dana Desa (ADD) (Oki \& Lafu, 2019; Tumbelaka et al., 2020).

Dana tersebut, umumnya dialokasikan dalam rangka memberdayakan masyarakat dan pembangunan infrastruktur desa. Dana desa bertujuan untuk mengoptimalkan layanan untuk masyarakat, program pemberdayaan masyarakat, meningkatkan perekonomian, pemerataan pembangunan, dan menekankan peranan aktif masyarakat dalam pembangunan (Dwiningwarni \& Amrulloh, 2020; Oki et al., 2020). Berdasarkan Pasal 1 Undang-Undang Nomor 6 Tahun 2014 tentang Desa, Desa mempunyai kewenangan lokal dalam mengatur rumah tangganya (Jamaluddin et al., 2018; Sofitriana et al., 2020). Dalam implementasinya terhadap pembangunan desa, kewenangan tersebut dimulai dari proses perencanaan, pelaksanaan dan pertangungjawaban kegiatan (Ayem \& Kusumasari, 2020; Ningsih et al., 2020; Polidu et al., 2020). Di sisi lain, dengan dilimpahkannya kewenangan terhadap desa, maka dibutuhkan perhatian lebih untuk mengawal pelaksanaannya agar sesuai dengan tujuan dan sasaran yang ditetapkan (Astuti et al., 2020).

Beberapa penelitian tentang pengelolaan dana desa antara lain penelitian Riyanto (2015), Julita \& Abdullah (2020) menyimpulkan bahwa pentingnya akuntabilitas dan transparansi dalam pengelolaan Anggaran Dana Desa. Widagdo et al., (2016) menyimpulkan dalam penelitiannya bahwa masih terjadi hambatan dalam pengelolaan ADD, khusunya berkaitan dengan rendahnya SDM aparatur desa dan minimnya koordinasi. Penelitian Chandra et al., (2012) menyimpulkan bahwa masih rendahnya sistem pengawasan dalam pengelolaan dana desa. Penelitian Ria et al., (2016) menyimpulkan bahwa hambatan dalam pengelolaan ADD adalah berkaitan dengan minimnya sosialisasi dan rendahnya partisipasi masyarakat. Sementara menurut Tikollah dan Ngampo (2018) menyimpulkan bahwa hambatan dalam pengelolaan ADD berkaitan dengan minimnya kemampuan SDM dan kurangnya kerjasama dari pihak terkait. Penelitian Jamaluddin et al., (2018) juga menegaskan bahwa pengelolaan dana desa masih terkendala terutama belum tepat sasaran terkait dengan penggunaan dana desa.

Penelitian ini difokuskan pada pengelolaan dana Desa yang merujuk pada Desa Pranten. Desa Pranten menjadi salah satu desa dengan anggaran penerimaan dan pembangunan cukup rendah. Berdasarkan data Statistik Kecamatan Gubung dalam angka 2019 menunjukkan bahwa dalam 3 tahun terakhir mulai tahun 2016 sampai 2018 mengalami penurunan terutama di tahun 2018. Di tahun 2016 dan 2017 memiliki besaran yang sama yaitu sebesar Rp. 293.100.000, sedangkan tahun 2018 mengalami penurunan menjadi Rp. 275.374.000. Penurunan ini menunjukkan bahwa serapan anggaran di Desa tersebut masih tergolong rendah, sehingga menunjukkan bahwa masih terdapat permasalahan dalam pengelolaan dana tersebut. Berdasarkan latar belakang tersebut, maka tujuan umum studi ini adalah untuk menganalisis pengelolaan dana Desa pada Desa Pranten Kecamatan Gubug Kabupaten Grobogan. Tujuan khususnya adalah untuk mengetahui bagaimana mekanisme pengelolaan dan pengalokasian dana Desa, untuk mengetahui bagaimana pemanfaatan dan pengalokasian dana Desa? dan untuk mengetahui apa kendala dalam pengelolaan dana Desa. 


\section{Metode Penelitian}

Penelitian ini menggunakan metode kualitatif. Pendekatan ini digunakan bertujuan untuk mengeksplorasi lebih komprehensif, lebih bermakna dan mendalam, serta lebih kredibel. Penelitian tentang pemanfaatan dan pengelolaan Dana Desa dilakukan di Desa Pranten Kecamatan Gubug Kabupaten Grobogan. Data yang digunakan dalam penelitian yaitu data primer dan sekunder. Data primer diperoleh proses in depth interview dengan para informan pada bulan September 2020, sementara data sekunder diperoleh melalui proses penelusuran data dukung berupa laporan keuangan desa, laporan kegiatan desa, website, dan juga data-data yang diperoleh melalui hasil penelitian dan data-data lain yang relevan dengan penelitian ini. Teknik pengumpulan data dalam penelitian ini dilakukan melalui tiga teknik, yaitu teknik observasi, wawancara, dan dokumentasi. Wawancara yang dilakukan dengan menggali informasi kepada para informan yang meliputi Kepala Desa, Sekretaris Desa, Bendahara Desa, dan pejabat lain yang terkait. Hasil wawancara tersebut, diperkuat melalui hasil dokumentasi terhadap data-data dukung, yang meliputi berbagai laporan yang relevan dengan penelitian ini. Teknik analisis data menggunakan pendekatan deskriptif. Menurut Meolong (2009) dalam Oki \& Lafu (2019), teknik analisis data dalam penelitian ini menggunakan pendekatan kualitatif deskriptif, yang meliputi 3 tahapan, yang meliputi:

1. Reduksi data, yang merupakan proses pemilihan, pemusatan, perhatian, penyederhanaan, pengabstrakkan, dan transformasi data kasar yang diperoleh berdasarkan data lapangan, proses ini akan berjalan secara simultan. Reduksi data itu sendiri, meliputi: proses meringkas data, pengkodean data, penelusuran tema, dan membuat gugus-gugus.

2. Penyajian data, merupakan proses kegiatan mengumpulkan berbagai informasi dan kemudian disajikan, yang nantinya dapat memberikan kemungkinan untuk membuat sebuah kesimpulan dan menjadi dasar dalam pengambilan keputusan. Penyajian data kualitatif dapat berbentuk teks narasi, matriks, grafik, dan jaringan, serta bagan.

3. Penarikan kesimpulan, merupakan proses terakhir dalam kajian ini, namun demikian proses verifikasi akan dilakukan secara simultan, terutama ketika berada di lapangan. Dari permulaan pengumpulan data, mulai mencari arti benda-benda, mencatat keteraturan pola-pola (dalam catatat teori), penjelasan-penjelasan, konfigurasi-konfigurasi yang mungkin, alur sebab akibat, dan proposal.

\section{Hasil Penelitian dan Pembahasan}

\section{Pengelolaan Dana Desa}

Pengelolaan dana desa merupakan bagian dari pengelolaan keuangan dari berbagai sumber baik dari pemerintah pusat, daerah maupun dana mandiri. Proses pengelolaan ini meliputi perencanaan, pengorganisasian, pelaksanaan, pengawasan, dan pertanggungjawaban (Handiyono \& Lutfi, 2020). Adapun pengelolaan Dana Desa pada Desa Pranten Kecamatan Gubug Kabupaten Grobogan, dilakukan melalui beberapa tahapan.

\section{Perencanaan}

Perencanaan dalam hal ini berkaitan dengan APBDes merupakan salah satu sumber pendapatan desa yang penggunaannya terintegrasi dengan Alokasi Dana Desa (ADD) (Bima et al., 2020). Oleh karena itu dalam perencanaan program dan kegiatannya dibahas dalam forum Musyawarah Perencanaan Pembangunan Desa (MUSRENBANGDES) yang dilakukan setiap tahunnya, dimana prosesnya melalui beberapa tahapan. Tahapan pertama yaitu Pra Musyawarah. Pada tahapan ini Tim Fasilitasi Tingkat Kabupaten memberikan petunjuk teknis musyawarah perencanaan pembangunan desa kepada Camat dan Tim pendamping Tingkat Kecamatan, Kepala Desa dan tim Pelaksana Desa, ketua BPD serta ketua lembaga kemasyarakatan yang ada di desa. Tahapan berikutnya adalah Musyawarah Perencanaan Pembangunan tingkat desa mempedomani surat Bupati Grobogan No. 148/4249/II tanggal 21 Oktober 2009 perihal petuntuk teknis Musyawarah Perencanaan Pembangunan Desa. Pemerintah desa bersamasama dengan Tim Pelaksana Desa, Badan Permusyawaratan Desa (BPD), Lembaga Pemberdayaan Masyarakat Desa (LPMD), dan lembaga kemasyarakatan yang ada di desa (seperti PKK, RT/RW, 
Studi Akuntansi \& Keuangan Indonesia

karangtaruna, dll) dengan difasilitasi Camat melakukan musrenbangdes guna membahas usulan atau masukan tentang rencana kegiatan pembangunan di tingkat desa termasuk rencana penggunaan ADD dengan berpedoman pada prinsip-prinsip anggaran dan Perencanaan Partisipasi Pembangunan Masyarakat Desa (P3MD).

Di Desa Pranten terdiri dari 3 RW dan 9 RT, dari masing-masing RT mengajukan 3 pembangunan baik berupa infrastruktur maupun penyelenggaraan lainnya. Sehingga didapatkan 27 pengajuan pembangunan, namun secara keseluruhan dilaksanakan tidak mungkin. Oleh karena itu adanya penyaringan dengan lebih mengedepankan yang mendesak dan ungent. Sebagian besar penduduk di desa Pranten berprofesi sebagai petani, namun jalan akses menuju lahan pertanian banyak yang mengalami kerusakan. Oleh karena itu pada tahun 2017 warga desa Pranten telah menyepakati bahwa sebagian besar dana ADD akan dialokasikan untuk pembangunan jalan.

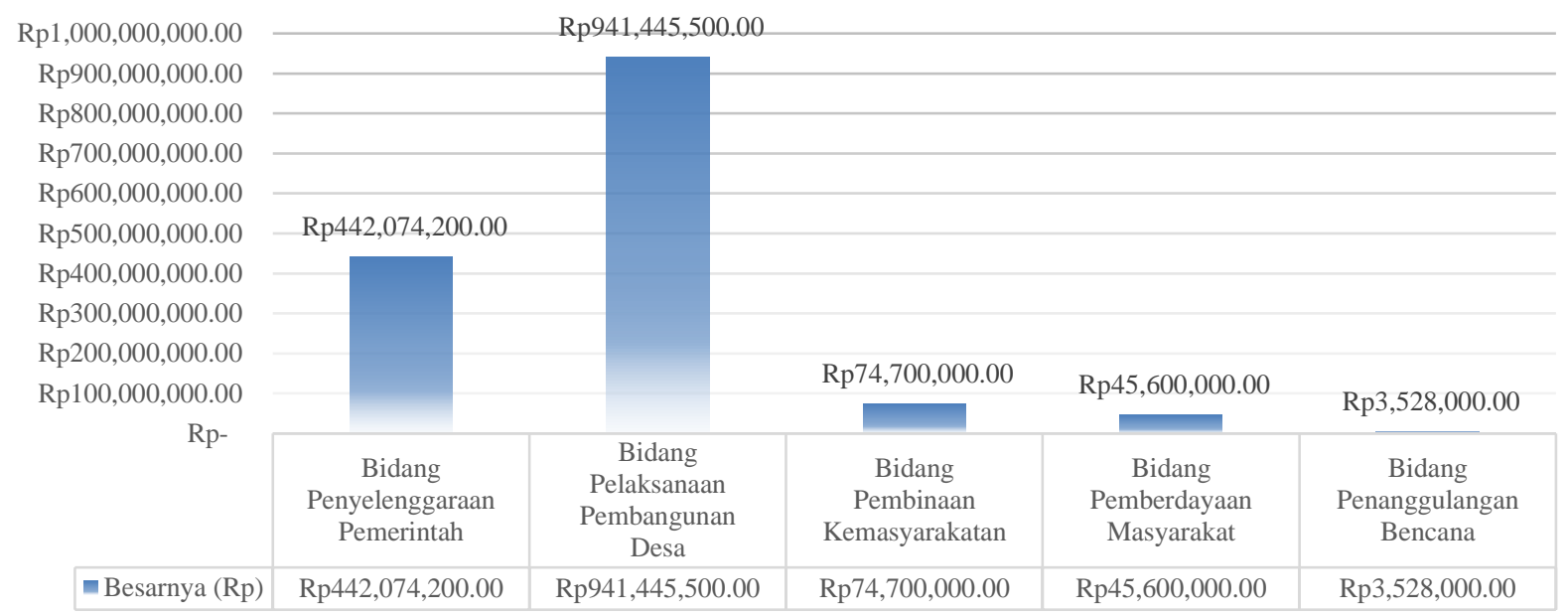

\section{Gambar 1. Alokasi Dana Desa Tahun 2018/2019 di Desa Pranten Kecamatan Gubug Kabupaten Grobogan}

Berdasarkan gambar 1. bidang pemberdayaan masyarakat menjadi prioritas alokasi dana desa. Program pemberdayaan ini dilakukan dengan tujuan agar perekonomian masyarakat menjadi tumbuh (Jatmiko, 2020). Hal ini dilakukan juga dalam rangka pemerataan pendapatan masyarakat, terutama para masyarakat yang memiliki kondisi perekonomian yang lemah. Pemerintah desa dalam penggunaan anggaran perlu adanya tranparansi sebagai bentuk dari pertanggungjawaban pemerintah desa. Dalam mengimplementasikan transparansi penggunaan anggaran, salah satu langkah yang dilakukan adalah dengan menginformasikan kepada masyarakat melalui beberapa media, mulai dari offline maupun online. Media offline yang sering digunakan adalah melalui papan pengumuman/informasi, sedangkan online dapat diimplementasikan melalui media website. Informasi yang disampaikan memuat seluruh rencana alokasi ADD dan APBDes ataupun dana lainnya. Meskipun demikian, informasi yang sudah disampaikan melalui beberapa media tersebut, menemui beberapa kendala. Kendala tersebut merujuk pada pemenfaatan informasi yang terbatas pada kalangan tertenmmttu saja. Dengan demikian, akses informasi terkait dengan penggunaan anggaran tersebut masih terbatas atau belum dapat diakses dengan mudah.

\section{Pengorganisasian}

Dalam mengelola Anggaran Dana Desa, Desa Pranten membentuk tim pelaksana pembangunan yang ditunjuk Kepala Desa melalui sebuah rapat. Namun demikian, Kepala Desa belum menjabarkan secara detil uraian tugas pokok dan fungsi yang harus dilaksanakan oleh para aparat pengelola ADD. Kekurangan juga terlihat pada terbatasnya kemampuan SDM baik dari sisi pendidikan maupun tanggungjawab. Dengan adanya keterbatasan tersebut, sehingga ada beberapa SDM yang bekerja tidak sesuai dengan tugas dan fungsinya, serta ada sebagian kecil SDM yang mendapatkan tugas berlebih. Berdasarkan Peraturan Bupati No.4 Tahun 2012 tentang Pedoman Pengelolaan Kekayaan Desa menjelaskan bahwa "Kepala Desa sebagai Kepala Pemerintah Desa adalah Pemegang Kekuasaan 
Pengelolaan Keuangan Desa dan mewakili Pemerintah Desa dalam kepemilikan kekayaan desa yang dipisahkan, mempunyai kewenangan: Menetapkan kebijakan tentang pelaksanaan APBDesa, Menetapkan kebijakan tentang pengelolaan barang desa, Menetapkan bendahara desa, Menetapkan petugas yang melakukan pemungutan penerimaan desa; dan Menetapkan petugas yang melakukan pengelolaan barang milik desa".

\section{Pelaksanaan APBDes}

Dengan terbentuknya tim panitia pelaksana pembangunan mempermudah dan memperlancar terlaksananya kegiatan-kegiatan pembangunan desa yang pembiayaannya bersumber dari APBDesa. Dalam pelaksanaan pembangunan selain dari tim panitia pelaksana dan Kepala Desa juga melibatkan masyarakat sebagai pekerja pembangunan. Hal ini dilakukan agar dapat memberdayakan masyarakat setempat dan terbentuknya gotong royong, selain itu juga mengurangi pengangguran di desa Pranten. Dalam pelaksanaan pembangunan dilakukan sesuai Rencana Anggaran Pelaksanaan (RAP) diawal yang telah diajukan di Kecamatan dan telah disepakati. Sebelum memulai pembangunan dari pihak Kecamatan akan melakukan pengecekan material beserta rincian dana yang dikeluarkan yang didampingi oleh Kepala Desa. Selanjutnya dalam proses pembangunan juga dilakukan pengecekan ulang oleh pihak Kecamatan untuk mengetahui baik kendala-kendala yang dihadapi maupun keabsahan dalam pembangunan. Setelah selesai pembangunan, dari pihak Kecamatan juga melakukan pengecekan. Kemudian pengecekan finishing dari pihak Kecamatan lengkap dengan Camat, selain itu juga ada pengecekan dari Kabupaten.

Selama berlangsungnya pelaksanaan pembangunan terdapat beberapa kendala salah satunya terjadinya perubahan cuaca yang tidak menentu. Sehingga mengakibatkan terhambatnya proses pelaksanaan pembangunan yang bedampak mundurnya penyelesaian yang tidak sesuai target. Dalam hal pelaksanaan Anggaran Dana Desa masih tergolong rendah. Hal ini tampak pada jumlah pelaksanaan program-program yang didanai dari alokasi dana desa masih belum tertib administratif. Penyusunan kebijakan desa belum mencerminkan tahapan dari proses penyusunan peraturan desa. Kondisi sosial, ekonomi dan kultur termasuk tingkat pendidikan yang rendah dari masyarakat juga mempengaruhi pelaksanaan program-program pembangunan desa Pranten. Terlaksananya pembangunan di desa Pranten diharapkan dapat memberikan manfaat yang lebih terutama dalam peningkatan kesejahteraan masyarakat. Sebagai contoh pembangunan di RW 1 berupa jalan, talup jalan, dan saluran irigasi sawah. Pembangunan tersebut memberikan manfaat kepada masyarakat banyak dan dapat meningkatkan hasil pertanian di desa Pranten.

\section{Pengawasan}

Tahapan pengawasan dalam pengelolaan dana desa mencakup pada beberapa hal, antara lain pengawasan dalam tahapan perencanaan, penyusunan, pelaksanaan, perubahan anggaran, dan pembuatan laporan keuangan dan kegiatan (Arfiansyah, 2020; Pahlawan et al., 2020). Tujuan adanya pengawasan ini antara lain, yaitu; 1) Memastikan bahwa program berjalan dengan baik. 2). Memastikan kesesuaian antara perencanaan dan pelaksanaan, jika belum sesuai atau sudah sesuai akan tetapi belum optimal dapat diselesaikan dengan segera. 3). Mampu mengidentifikasi permasalahan dan mampu memberikan solusi. 4). Adanya evaluasi agar tidak terjebak pada masalah yang sama. Dalam pengawasan pelaksanaan pembangunan di desa Pranten dalam kegiatan ADD dilakukan secara fungsional oleh pejabat berwenang dan oleh masyarakat sesuai Peraturan Perundang-undangan yang berlaku. Sebagai mana pengawasan yang dilakukan oleh pihak kecamatan dan kabupaten dimana sebelum pembangunan sampai selesai pembangunan selalu melakukan pengecekan di lapangan langsung.

\section{Laporan Pertanggungjawaban APBDes}

Laporan pertanggunjawaban harus dibuat paling tidak tiga bulan setelah berakhirnya tahun anggaran desa. Laporan tersebut berkaitan dengan pelaksanaan atau implementasi penggunaan APBDes dalam rangka menerapkan prinsip transparansi dan akuntabilitas (Babulu, 2020; Budiarto et al., 2020; Pahlawan et al., 2020). Proses penyusunan laporan pada desa Pranten dimulai dengan penyusunan rancangan Peraturan Desa tentang pertanggung-jawaban implementasi APBDes dan penyusunan rancangan keputusan kepala desa tentang pertanggungjawaban kepala desa. Tahapan berikutnya 
Studi Akuntansi \& Keuangan Indonesia

sekretaris desa menyampaikan kepada kepala desa untuk dibahas bersama dengan BPD, kemudian proses selanjutnya adalah menetapkan rancangan peraturan desa tentang pertanggungjawaban pelaksanaan APBDesa yang menjadi peraturan desa. Setelah melakukan pembahasan bersama Kepala Desa dengan BPD mengenai laporan pertanggungjawaban, selanjutnya Kepala Desa menyampaikan laporan realisasi fisik dan Keuangan ADD kepada pihak Kecamatan. Apabila terjadi kesalahan dalam pelaporan maka laporan pertanggungjawaban tersebut akan dikembalikan di desa. Dan pihak desa akan melakukan perbaikan. Dari pihak Kecamatan akan menyampaikan laporan hasil rekapitulasi dari seluruh laporan tingkat desa kepada Bupati.

Azas transparansi dan akuntabilitas pada pengelolaan dana desa di desa Pranten belum sepenuhnya berjalan optimal. Hal ini salah satunya terindikasi dari rendahnya akses masyarakat terhadap informasi tentang pengelolaan dana tersebut. Disamping itu, dalam proses pelaporan masih terkendala pada aspek pengorganisasian yang belum berjalan optimal, hal ini dapat terindikasi pada pembagian jobdesk yang belum sesuai dengan yang seharusnya. Untuk menuju pertanggung-jawaban yang baik sesuai dengan peraturan yang ditetapkan oleh Pemerintah Pusat. Dalam pengelolaan keuangan desa harus dilakukan secara transparansi dengan membuat dan menginformasikan setiap pemasukan dan pengeluaran dana desa berbentuk Metromedia Technologies (MMT) yang di pasang di balai desa. Selain itu Kepala Desa juga harus lebih teliti dalam pemilihan perangkat desa, yaitu yang berpendidikan, berkompeten, dan tanggap. Agar dapat melakukan tugasnya sesuai peraturan yang berlaku.

\section{Faktor Penghambat dalam Pengelolaan Dana Desa}

Dalam pengelolaan dana desa menemui berbagai kendala. Ada beberapa faktor yang menjadi penghambat, yaitu masalah sumber daya manusia, masalah sistem, media sosialisasi dan komunikasi, dan peranan masyarakat. Masalah sumber daya manusia berkaitan dengan minimnya SDM dan juga rendahnya kemampuan SDM dalam mengoptimalkan pengelolaan dana desa tersebut (Islamiyah, 2020). Berdasarkan hasil wawancara menunjukkan bahwa permasalahan SDM di Desa Pranten berkaitan dengan ketersediaan (jumlah) dan kualitas SDM (tingkat pendidikan). Permasalahan ini berdampak pada pembagian tugas pokok (job desk) dan fungsi yang kurang sesuai dan bahkan ada sebagian yang mendapatkan tugas berlebih. Masalah berkaitan dengan belum optimalnya penggunaan sistem berbasis online berkaitan dengan sistem pelaporan belum berbasis sistem yang terintegrasi (Pratiwi \& Pravasanti, 2020). Hal ini disebabkan karena belum adanya SDM yang memiliki kemampuan dalam mengelola sistem tersebut. Bahkan sampai pada saat wawancara berlangsung desa Pranten belum memiliki website dan ataupun sistem online lainnya yang berkaitan dengan pengelolaan anggaran Desa, sehingga akses masyarakat untuk mengakses informasi tersebut masih terbatas informasi offline di papan pengumuman ataupun MMT. Masalah berkaitan dengan media sosialisasi dan komunikasi merujuk pada kurang optimalnya penggunaan media sosialisasi dan komunikasi yang dapat diakses dengan mudah oleh masyarakat, sehingga masyarakat banyak yang tidak tahu informasi terkait dengan ADD. Terakhir, masalah berkaitan dengan peranan masyarakat (Periansya \& AR, 2020). Pada faktor ini berpengaruh cukup fundamental, karena pada dasarnya keberhasilan dari program ini terletak pada sejauh mana masyarakat berperan aktif dalam pembangunan desa. Hal ini terjadi karena sebagian masyarakat masih bersikap tidak peduli terhadap program tersebut, dan lebih terlihat bahwa masyarakat menyerahkan pada pemerintah desa.

\section{Kesimpulan, Implikasi, dan Keterbatasan}

Berdasarkan pembahasan di atas dapat disimpulkan bahwa pengelolaan dan pemanfaatan Anggaran Dana Desa dimulai dari proses perencanaan APBDes melalui MUSRENBANGDES, pengorganisasian dilakukan dengan menunjuk tim pengelola dana desa, pelaksanaan dilakukan oleh tim pembangunan, pengawasan dimulai dari perencanaan sampai pelaporan, dan pelaporan pertanggungjawaban APBDes. Pemanfaatan dana desa dialokasikan pada bidang penyelenggaran pemerintah, pelaksaan pembangunan, pembinaan masyarakat, pemberdayaan masyarakat, dan penanggulangan bencana. Kendala dalam pengelolaan alokasi dana desa antara lain masalah SDM, minimnya sistem, masalah kepemimpinan, minimnya sosialisasi dan komunikasi, serta rendahnya peran masyarakat. Dengan demikian, pemerintah Desa Pranten perlu meningkatkan kualitas Pemerintahan, baik dari sisi SDM maupun sistem pengelolaan dana Desa, yang tidak kalah penting adalah melibatkan 
berbagai pihak terkait terutama membangun komunikasi yang baik kepada seluruh komponen masyarakat.

Implikasi secara praktis dari penelitian ini, perlu adanya upaya perbaikan dari berbagai aspek, sehingga kedepan pengelolaan dana desa di desa Pranten dapat berjalan lebih optimal. Bagi institusi pemerintahan Desa, perlu adanya perbaikan baik dari sisi sistem pengelolaan anggaran berbasis online, peningkatan kuantitas dan kualitas sumber daya manusia, serta memperluas media sosialisasi dan komunikasi, agar pengelolaan anggaran dana desa kedepan dapat dilaksanakan sesuai dengan ketentuan dan dapat dioptimalkan dari sisi hasil atau dampaknya. Bagi masyarakat, perlu meningkatkan partisipasi aktif dalam bentuk apapun agar kemajuan yang diharapkan dapat diimplementasikan secara bersamasama.

Studi ini memiliki keterbatasan, terutama berkaitan dengan pemilihan lokasi penelitian dan studi ini juga belum sampai pada pengukuran kinerja yang dikaji secara kuantitatif, sehingga peneliti selanjutnya perlu adanya mengembangkan kajian ini dengan menguji secara kuantitatif tentang kinerja dari pengelolaan dana desa, seberapa berhasil Desa dalam mengelola dana tersebut.

\section{Daftar Pustaka}

Arfiansyah, M. A. (2020). Pengaruh Sistem Keuangan Desa dan Sistem Pengendalian Intern Pemerintah Terhadap Akuntabilitas Pengelolaan Dana Desa. Journal of Islamic Finance and Accounting, 3(1), 67-82.

Astuti, E., Murwani, J., \& Sugiharto. (2020). Pelatihan Akuntansi Pemerintahan dan Pengelolaan Dana Desa Pada MGMP Kabupaten Madiun. DINAMISIA: Jurnal Pengabdian Kepada Masyarakat, 4(2), 214-221.

Ayem, S., \& Kusumasari, K. F. (2020). Pengaruh Sistem Pengendalian Intern Pemerintah ( SPIP ) Terhadap Pencegahan Fraud dalam Pengelolaan Dana Desa dengan Akuntabilitas Sebagai Variabel Mediasi. Jurnal Ilmiah Akuntansi Dan Humanika, 10(2), 160-169.

Babulu, N. L. (2020). Faktor-Faktor Yang Mempengaruhi Akuntabilitas Dalam Pengelolaan Dana Desa dan Dampaknya Terhadap Pencegahan Fraud. Jurnal Ekonomi Pembangunan, 5(2), 18-26.

Bima, M. R., Kamal, M., \& Djanggih, H. (2020). Pelatihan dan penyuluhan pengelolaan alokasi dana desa (ADD). Jurnal Inovasi Hasil Pengabdian Masyarakat (JIPEMAS), 3(1), 63-77.

Budiarto, D. S., Setyaningrum, A. D., \& Sari, R. P. (2020). Akuntabilitas Pengelolaan Dana Desa dan Faktor Anteseden yang Mempengaruhinya. WAHANA: Jurnal Ekonomi, Manajemen Dan Akuntansi, 23(2), 145159. https://doi.org/10.35591/wahana.v23i2.240

Chandra, K. P., Ratih, N. P., \& Suwondo. (2012). Pengelolaan Alokasi Dana Desa Dalam Pemberdayaan Masyarakat Desa (Studi pada Desa Wonorejo Kecamatan Singosari Kabupaten Malang) Chandra Kusuma Putra, Ratih Nur Pratiwi, Suwondo. Jurnal Administrasi Publik (JAP), 1(6), 1203-1212.

Dwiningwarni, S. S., \& Amrulloh, A. Z. (2020). Peranan Pengelolaan Dana Desa Untuk Meningkatkan Pendapatan Masyarakat Di Jombang Jawa Timur. Ekuitas: Jurnal Ekonomi Dan Keuangan, 4(1), 1-20. https://doi.org/10.24034/j25485024.y2020.v4.i1.4128

Handiyono, V. J., \& Lutfi, A. (2020). Penerapan Sistem Pengendalian Internal Pengelolaan Dana Desa Tahun 2018 (Desa Tambun Dan Desa Segarajaya). Dinamika Governance: Jurnal Ilmu Administrasi Negara, 10(2), 101-119. https://doi.org/10.33005/jdg.v10i2.2341

Inten, M. L. (2017). Pengelolaan Keuangan Dana Desa. Jurnal Akuntansi Multiparadigma (JAMAL), 8(2), $227-$ 429.

Islamiyah, F. (2020). Pengaruh Kompetensi Aparatur Desa, Moralitas, Sistem Pengendalian Internal, Dan Whistleblowing Terhadap Pencegahan Fraud Dalam Pengelolaan Dana Desa Di Kecamatan Wajak (Studi Empiris Pada Desa Sukoanyar, Desa Wajak, Desa Sukolilo, Desa Blayu dan Desa Pato. Jurnal Riset Mahasiswa Akuntansi (JRMA), 8(1), 1-13.

Jamaluddin, Y., Sumaryana, A., Rusli, B., \& Buchari, R. A. (2018). Analisis Dampak Pengelolaan dan Penggunaan Dana Desa terhadap Pembangunan Daerah Analysis of the Impact of Management and Use of Village Funds on Regional Development. JPPUMA: Jurnal Ilmu Pemerintahan Dan Sosial Politik UMA, 6(1), 14-24.

Jatmiko, U. (2020). Pemberdayaan Ekonomi Berbasis Kearifan Lokal Sebelum dan Sesudah Pengalokasian Dana Desa. JMK (Jurnal Manajemen Dan Kewirausahaan), 5(2), 107-121.

Julita, E., \& Abdullah, S. (2020). Transparansi Dalam Pengelolaan Dana Desa (Studi Di Kecamatan Sukakarya Kota Sabang). Jurnal Ilmiah Mahasiswa Ekonomi Akuntansi (JIMEKA), 5(2), 213-221.

Ningsih, W., Arza, F. I., \& Sari, V. F. (2020). Analisis Akuntabilitas Pengelolaan Alokasi Dana Desa (Studi Kasus Pada Empat Desa Dalam Empat Kecamatan di Kota Sawahlunto Provinsi Sumatera Barat ). Jurnal Eksplorasi Akuntansi, 2(4), 3517-3532. 
Studi Akuntansi \& Keuangan Indonesia

Oki, K. K., \& Lafu, D. M. (2019). Analisis Pengelolaan Dana Desa Noebaun Kabupaten Timor Tengah Utara. Ekuivalensi Jurnal Ekonomi Bisnis, 5(2), 203-232.

Oki, K. K., Pangastuti, M. D., \& Ua, N. (2020). Pengaruh Pengelolaan Alokasi Dana Desa Terhadap Pemberdayaan Dan Peningkatan Kesejahteraan Masyarakat Desa Maurisu Selatan Kecamatan Bikomi Selatan. Jurnal Ekonomi Pembangunan, 5(1), 65-72.

Pahlawan, E. W., Wijayanti, A., \& Suhendro. (2020). Pengaruh kompetensi aparatur desa, sistem pengendalian internal, pemanfaatan teknologi informasi dan partisipasi masyarakat terhadap akuntabilitas pengelolaan dana desa. Indonesia Accounting Journal, 2(2), 162-172.

Periansya, \& AR, S. (2020). Dampak kompetensi dan partisipasi masyarakat terhadap akuntabilitas pengelolaan dana desa Decamatan Rambutan Banyuasin. Jurnal Riset Terapan Akuntansi, 4(1), 13-19.

Polidu, I., Tumuhulawa, A., Kasim, R., Kadir, Y., \& Moonti, R. M. (2020). Peran Inspektorat Dalam Sistem Pengawasan dan Pengendalian Pengelolaan Dana Desa: Studi Inspektorat Kabupaten Gorontalo Utara. Law Review Volume, $X X(2), 226-245$.

Pratiwi, D. N., \& Pravasanti, Y. A. (2020). Analisis Penggunaan Siskeudes dalam Pengelolaan Dana Desa. Jurnal Akuntansi Dan Pajak, 20(2), 217-223.

Ria, N., Sudati, N. S., \& Emma, D. R. (2016). Analisis Pengelolaan Dana Desa Sebagai Realisasi Salah Satu Tujuan Program Nawacita "Membangun Indonesia Dari Pinggiran" Di Kecamatan Bener Kabupaten Purworejo Tahun. DINAMIC : Directory Journal of Economic Volume, 1(2), 136-150.

Riyanto, T. (2015). Akuntabilitas Finansial Dalam Pengelolaan Alokasi Dana Desa (Add) Di Kantor Desa Perangat Selatan Kecamatan Marangkayu Kabupaten Kutai Kartanegara. EJournal Administrasi Negara, 3(1), 119_ 130. https://doi.org/10.1017/CBO9781107415324.004

Saputra, I. W. (2016). Efektivitas Pengelolaan Alokasi Dana Desa Pada Desa Lembean Kecamatan Kintamani, Kabupaten Bangli Tahun 2009-2014. Jurnal Jurusan Pendidikan Ekonomi (JJPE), 6(1).

Sofitriana, I., Hartati, E. R., Rizki, N., Muammar, A., \& Lutfi, T. (2020). Analisis Pengelolaan Dana Desa Dalam Perspektif Peraturan Menteri Dalam Negeri Nomor 113 Tahun 2014 Di Desa Polobogo, Getasan Kabupaten Semarang. Intelektiva : Jurnal Ekonomi, Sosial \& Humaniora, 01(08), 28-36.

Tikollah, M. R., \& A. Ngampo, M. Y. (2018). Analisis Pengelolaan Alokasi Dana Desa (Add) Di Kecamatan Mare Kabupaten Bone. JEKPEND: Jurnal Ekonomi Dan Pendidikan, 1(1), 87. https://doi.org/10.26858/jekpend.v1i1.5064

Tumbelaka, H. I. A., Elim, I., \& Kalalo, M. (2020). Analisis pengelolaan dana desa studi kasus di Kecamatan Tatapaan Kabupaten Minahasa Selatan. Indonesia Accounting Journal, 2(2), 74-86.

Wida, S. A., Supatmoko, D., \& Kurrohman, T. (2017). Akuntabilitas Pengelolaan Alokasi Dana Desa (ADD) di Desa - Desa Kecamatan Rogojampi Kabupaten Banyuwangi. E-Journal Ekonomi Bisnis Dan Akuntansi, 4(2), 148. https://doi.org/10.19184/ejeba.v4i2.5356

Widagdo, A. K., Widodo, A., \& Ismail, M. (2016). Sistem Akuntansi Pengelolaan Dana Desa. Jurnal Ekonomi Dan Bisnis, 19(2), 323. https://doi.org/10.24914/jeb.v19i2.336

Yoga, A., Taufeni, T., \& Nur, A. (2019). Analisis Transparansi Partisipasi Dan Akuntanbilitas Pengelolaan Dana Desa (Studi Kasus pada Desa Sako Kecamatan Pangean Kabupaten Kuantan Singingi Provinsi Riau Tahun Anggaran 2018). Indonesian Journal of Accounting and Governance, 3(2), 120-143. 